\title{
The Bird of Boundaries: Beliefs and Folk Customs Surrounding the Chicken
}

\author{
KoIKe Jun'ichi \\ Translated by Elizabeth MARSH
}

\section{Introduction}

Chickens have lived alongside humans since ancient times. They have been used for various purposes and have been the focus of much attention, giving rise to a rich body of legends and traditions. In Japan, these birds have been projected prominently in art and literature, including notable appearances in monogatari and waka. In the present article, we will address the legends, rituals and magical thinking surrounding the chicken. We will consider its characteristics in folklore and its role in the traditional Japanese worldview, with the primary goal of investigating and positioning it among the art and literature of Japan.

Let us begin by reviewing past research and texts that have looked into the role of chickens in the field of folklore.

From early on, Yanagita Kunio 柳田國男 had been researching the relationship between the image of the chicken and gold in Japanese folklore. In his studies of legends published in the 1920s, he delineated the ways in which these birds have been linked to the treasures of the spirit world and to the genre of chojja densetsu 長者伝説, or “'millionaire legends.” Yanagita's Santō mintanshū 山島民譚集 (1914) contains a study titled Ogon no niwatori 黄金の雞 in which he addresses this topic. ${ }^{1}$ His work examines the reasoning behind the appearance of chickens in legends that contain reference to treasures, drawing on material from early modern investigations and topographical data. Following this, Minakata Kumagusu 南方 熊楠 published his Jünishiko 0 十二支考 which contains his studies on the sequence of the sexagenary cycle, among which he touches on the topic of chickens. ${ }^{2} \mathrm{~A}$ similar investigation has also been conducted by Miyatake Shōzō 宮武省三 in

\footnotetext{
${ }^{1}$ Yanagita Kunio 柳田國男, Zōho santō mintanshū 増補山島民譚集, eds. Seki Keigo 関敬吾 and Ōtō Tokihiko 大藤時彦, Tokyo: Heibonsha, 1969.

${ }^{2}$ Minakata Kumagusu 南方熊楠, “Tori ni kansuru densetsu”鷄に関する伝説, in Jünishikō十二 支考. Tokyo: Iwanami Shoten, 1994.
} 
which he refers to various legends involving chickens. ${ }^{3}$ For information on the role of the chicken in the daily life of Japan, there is Tori no hanashi sono ta 雞の 話其他 by Hayakawa Kōtarō 早川孝太郎, which records memories of the chicken in farm life until the early modern period. ${ }^{4}$

Later research on folk customs related to chickens largely adhered to Yanagita's views, while providing additional supporting data and materials. Yütsukedori 木綿 附鳥 by Takasaki Masahide 高崎正秀 includes an investigation of texts from Japanese classical literature, shedding much light on the historical development of oral transmissions and the human awareness of the chicken. ${ }^{5}$ Additionally, in Kinkei densetsu 金雞伝説, Ōtō Tokihiko 大藤時彦 provides an extensive study on such legends, expanding further on Yanagita's views. ${ }^{6}$

With literary investigations at its foundation, the study of chicken folklore has been developing steadily over time, through the contribution of reports from various regions. The present article will examine the formation process and reasoning behind such folklore, while drawing heavily on the data presented in the above works. Research available until this point has clarified the association between the chicken and boundaries in Japanese folk custom. In the present work, we aim to re-examine in even further depth, how and in what context such folklore came into being, and in what capacity they functioned.

In the following sections, we will begin by discussing early magic practices involving the use of chickens, followed by an investigation into folklore on the connection between chickens and the native Japanese gods. In the final section, we will consider legends in which the chicken appears, and will elucidate the relationship between these birds and boundaries.

\section{The Magical Powers of the Chicken}

In Seno (present day Mutsu), located in Wakinosawa village in the Shimokita district of Aomori, when boats capsized in the sea and the passengers could not be located, people would row out to the scene of the shipwreck with a hen aboard their boat. When the boat passed over a drowned body, it is said that the hen would let out a piercing cry and that upon hearing her call, the body would rise to the surface of the water. Similarly, in Cape Shiriya which lies on the Pacific coast of Higashidōri village on Shimokita Peninsula, whenever a boat capsized in the water, the people would light a fire on the shore, which they referred to as "the flame that welcomes the Buddha." Alternatively, they would take a boat to

\footnotetext{
${ }^{3}$ Miyatake Shōzō 宮武省三, “Tori ni kansuru densetsu to minzoku”雞に関する伝説と民俗, in Shüzoku zakki i習俗雑記. Tokyo: Sakamoto Shoten, 1927.

${ }^{4}$ Hayakawa Kōtarō 早川孝太郎, “Tori no hanashi sono ta”雞の話其他, Minzoku, 1: 1, 1925.

${ }^{5}$ Takasaki Masahide 高崎正秀, “Kintarō tanjō tan” 金太郎誕生譚, in Takasaki masabide chosakushù 高崎正秀著作集, vol. 7. Tokyo: Ōfūsha, 1971 (1937).

${ }^{6}$ Ōtō Tokihiko 大藤時彦, “Kinkei densetsu” 金雞伝説, in Nibon minzokugaku no kenkyū 日本民 俗学の研究. Tokyo: Gakuseisha, 1979 (1972).
} 
the scene of the accident and throw hand towels or other such pieces of cloth into the water, upon which it is said that the bodies of the deceased would surface. If the victims still could not be located, they would take a hen with them out into the water, and when they approached the location of the submerged body, the bird would cry out. ${ }^{7}$ Chickens were understood to possess the miraculous ability to sense the conditions of the sea. It is not entirely clear how far back we can trace such beliefs in the perceptive and magical powers of the chicken, but for the present we will take a look at some data that will shed further light on this matter.

The Wakun no shiori 倭訓刑 collection of dictionaries was first compiled by Tanikawa Kotosuga 谷川士清 in the An'ei 安永 6 (1777). In the latter portion of the fourteenth volume, there is a section titled Niwatoriにはとり, which states that "when searching for a submerged body, if you set out into the water in a boat, bringing [a chicken] with you, it is said that the chicken will cry out at the location of the body. This was practiced at Lake Suwa [in present day Nagano prefecture]." From this description, we know that the magical ritual of using chickens to search for submerged bodies was also performed at Lake Suwa.

Related to this, in Suzuki Bokushi's 鈴木牧之 Hokuetsu seppu 北越雪譜, there is record of chickens having been used to uncover missing people after an avalanche. ${ }^{8}$ (Figure 1)

In the main passage of this description, it is written that "[when someone once went missing in an avalanche] an elderly man said he knew of a technique for times such as these. He took a young man with him to the neighbouring village to procure some chickens, and after scattering feed over the snow, he allowed the birds to wander about freely. Upon doing so, although it was not yet dawn, one chicken crowed and the rest of the birds also joined in. [Thus, the missing body was discovered.] This technique was used when searching for bodies submerged under water, but to think of using such a method in the snow was extremely clever, and the people continued to praise his idea well into the future." From this account we can see that in the early modern era, the practice of using chickens to search for sunken bodies was widely known, and that there were instances when it was also applied in the wake of avalanches.

For us humans who dwell on land, the depths of the water and snow are distant realms beyond our imagining, and are difficult to even begin to grasp. To gain some insight into these unfamiliar territories, we rely on the power of the chicken and the special abilities it possesses, as revealed through the wondrous magic of its call.

This demonstrates that the chicken has the power to reveal to us the border

\footnotetext{
${ }^{7}$ Takamatsu Keikichi 高松敬吉, “Kainan shisha e no girei” 海難死者への儀礼, in Fuqoku to takaikan no min₹okugakuteki kenkyy 巫俗と他界観の民俗学的研究. Tokyo: Hōsei Daigaku Shuppankyoku, 1993.

${ }^{8}$ Suzuki Bokushi 鈴木牧之, Hokuetsu seppu 北越雪譜, vol. 1, middle section. Tenpō 天保 6, 1836.
} 


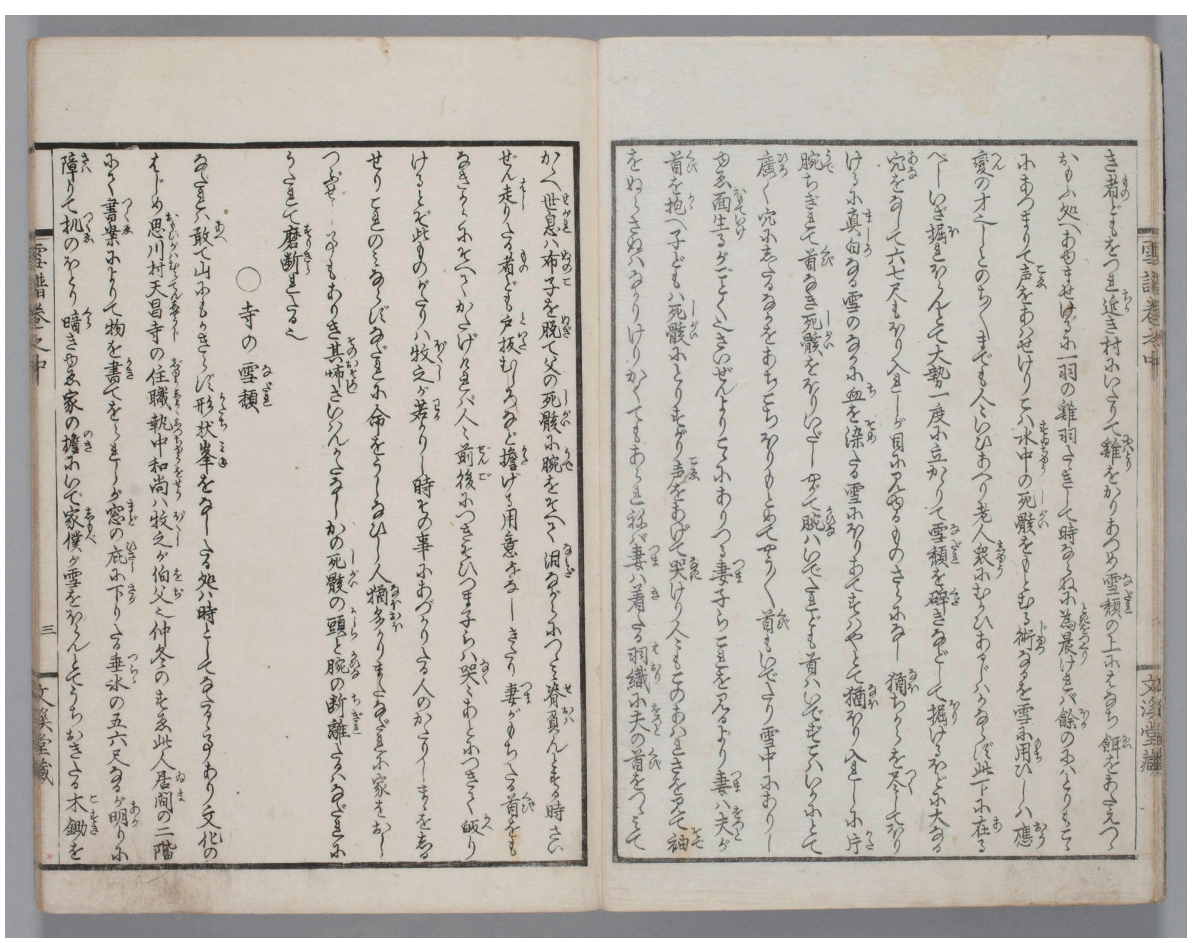

Figure 1. A method of using chickens to search for survivors buried under the snow. Suzuki Bokushi 鈴木牧之, “Nadare hito ni saisu” 雪頽人に災す, in part 1, volume 2 of Hokuetsu seppu 北越雪譜 初編巻之中 (NIJL).

https://doi.org/10.20730/200019786

between land and water, and that its crow can expose the barrier that separates this world from the afterlife. Thus, through its call, the chicken has become a symbol of the division between the land of the living and the land of the dead, and between life and death itself.

\section{Chickens and the Gods}

At Miho Shrine 美保神社 in Matsue city, Shimane prefecture, there is a legend that every night the tutelary deity crosses over to the opposite shore to visit a goddess. On one such occasion, a rooster crowed out at the wrong time, causing the god to hurry back to the shrine and injure himself in his haste. It is said that because of this, the god of Miho Shrine came to despise all chickens, and that in the town of Mihonoseki there is a taboo against owning chickens and eating eggs.

\footnotetext{
${ }^{9}$ Orikuchi Shinobu 折口信夫, “Keimei to kagura to” 鷄鳴と神楽と, in Orikuchi Shinobu zenshu 折口信夫全集 2. Tokyo: Chūō Kōron Shinsha, 1995 (1920).
} 


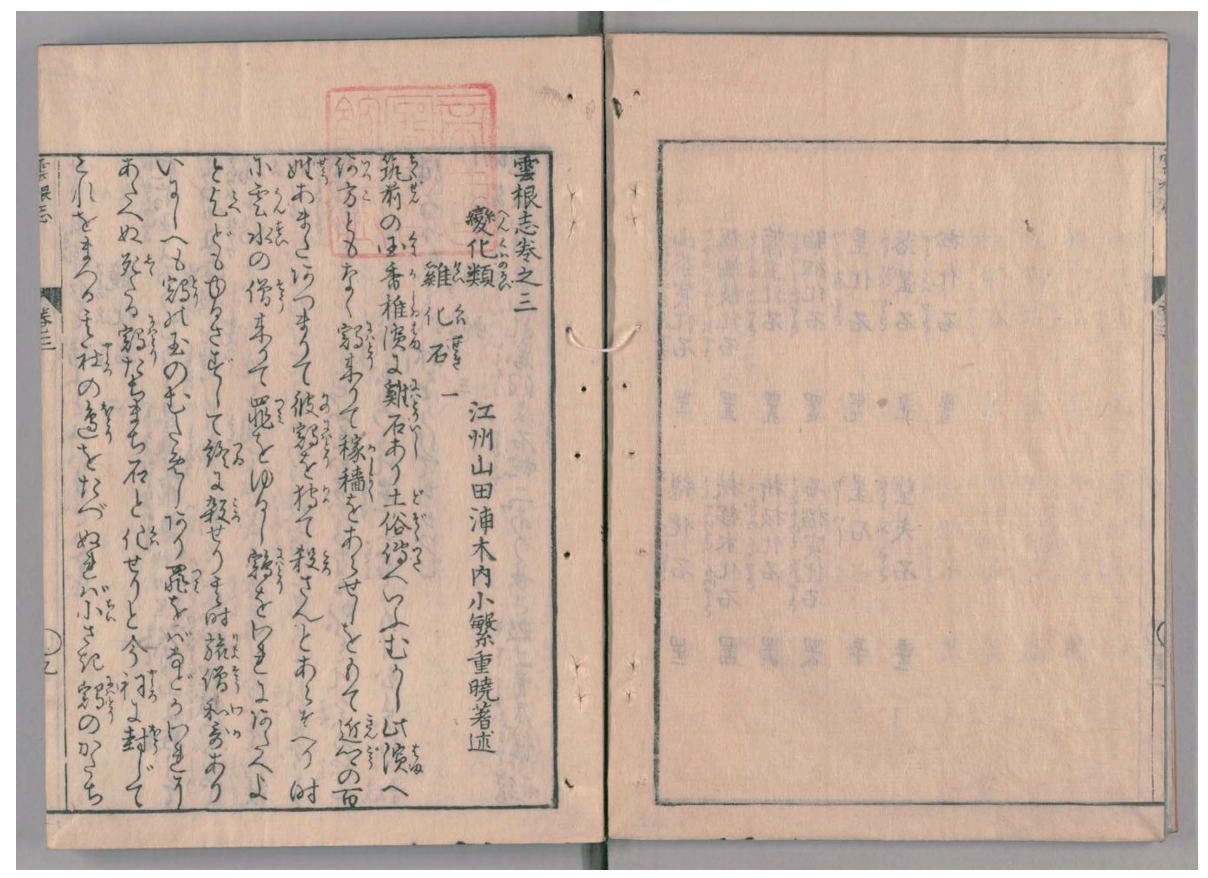

Figure 2. A chicken that has been turned to stone. Kiuchi Sekitei 木内石亭, “Henka rui: kei kaseki” 変化類 - 雞化石, in volume 3 of Unkonshi 雲根志 (National Diet Library, Japan).

https://doi.org/10.11501/2563667

Simply by carrying out its natural behaviour of crowing at dawn, the chicken ended up being loathed by the god of Miho Shrine. However, there is also a theory that the tabooed relationship between the two had already existed, and that the legend was created as a way of explaining this association. It seems that such a legend alludes to some sort of unique relationship or close connection that naturally existed between chickens and the Japanese deities.

In short, we can see that the chicken reveals to us the border between night and day, and symbolizes the point of contact between humans and the gods. This being the case, it would appear that the native Japanese gods share close ties to chickens, and that an investigation into the physical form of these birds and the various names assigned to them may shed light on the nature of this connection.

As one example which may provide some insight into this, below is a passage from the third volume of Kiuchi Sekitei's 木内石亭 Unkonshi 雲根志 (An'ei 2, 1773 to Kyōwa 享和 1, 1801), in which the legend of Kei kaseki 鷂化石 is recorded as follows. (Figure 2)

There is a keiseki雞石 in Kashiihama, Chikuzen Province. In the past, a chicken appeared in a seaside village and became troublesome to the local farmers, who then decided to kill it. Thereupon, a travelling monk came along and pleaded with them to forgive the chicken for its misdeeds. The people refused and the 
chicken was killed. In response, the monk composed a waka, upon which the chicken was immediately turned to stone and was enshrined in a bokora 祠 (small shrine). Following this incident, small rocks in the shape of a chicken could be collected from the area around the hokora. (The author has not personally seen such rocks.)

From this description, we can see that the chicken and its physical form came to be attributed with divine qualities.

In Soma, Fukushima, there are hokora dedicated to deities with such names as Niwatariニワタリ, Miwatariミワタリ, and Niwatashi ニワタシ. In the Japanese script, they are often written as 庭渡 (lit. garden crossing), 荷渡 (lit. baggage crossing), 御渡 (lit. honourable crossing), respectively, with each character being used for their phonetic quality rather than their semantic meaning. The names are uncertain and the deities themselves are not clearly defined. In everyday life, people commonly attributed them with various roles, including the granting of water, the ensuring of safe passage across the sea, and the healing of coughs.

For instance, atop a hill near a paddy field in Sekizawa, Iitate, there is a bokora dedicated to the chicken deity Niwatori daimyōjin 庭鳥大明神. It is said that long ago, a chicken was being chased by something and came to this hill, where it met its fate. The cry of the chicken is believed to resemble the sound of a person with a cold coughing violently and gasping for air, giving rise to its identification as a deity who heals coughs. In Ogawa, Shinchi, there is another bokora known as Niwatari二羽渡, which is dedicated to a pair of swans fabled to have once flown by and descended upon that spot. The deified birds are said to have the power to heal coughs, and drawings of a pair of chickens are given as offerings by visitors to the shrine. ${ }^{10}$ Niwatari and other similar gods had once existed in large numbers throughout Iwate, Miyagi and Fukushima prefectures. Their original meaning however was forgotten long ago, and we can see that folklore related to various divinities has since emerged.

It should be noted that the names of these deities, Niwatari, Miwatari, and Niwatashi, are suggestive of the traversal of water and that they are collectively associated with the niwatori (chicken). They are further identified with the border-related role of water distribution commonly attributed to the chicken, and are likewise thought to be linked to the barrier between land and water by guaranteeing safe passage through the sea. Moreover, the belief that they suppress coughs is not only rooted in the audible similarity between the cough and the call of the chicken, but in the idea that these gods are able to soothe the symptoms of the cough as it crosses the border from the inside of the human body to the outside world. The chicken, and the divinities that developed from it, remind us of the borders that exist across various settings.

\footnotetext{
${ }^{10}$ Iwasaki Toshio 岩崎敏夫, Honpō shōshi no kenkyū 本邦小祠の研究. Sōma: Iwasaki Hakushi Gakui Ronbun Shuppan Kōenkai, 1963.
} 


\section{Chicken Legends}

The description of Hiraizumi in Matsuo Bashō's 松尾芭蕉 Oku no hosomichi 奥 の細道 contains the following passage: “The splendor of three generations of the Oshū Fujiwara-shi 奧州藤原氏 has vanished. All that is visible are country fields, with not a single trace of their glorious era. It is now only Mount Kinkei (Kinkeizan 金鷂山) that remains.”

The name Mount Kinkei (lit. Golden Chicken Mountain) is rooted in the legend that Fujiwara no Hidehira buried a golden chicken in the soil. It is commonly known that numerous legends concerning golden chickens have also been transmitted throughout the Tōhoku region. For instance, in Matsura Seizan's 松浦静山 Kasshi yawa zokuben 甲子夜話続篇, Volume 13, there is a narrative about Ōtsuki Gentaku 大槻玄沢, in which the following passage is recorded.

In Hatamura, Sannohe in the Kurihara District of Ōshū, there is a place called Niwatorizaka (鶏坂, lit. Chicken Hill). Here, a chicken made of pure gold was once dug up from the ground. In the past, a charcoal maker named Tōta 藤太 used to live in this village. It is said that he discovered gold near his home and became very wealthy. Using this gold, he made a pair of golden chickens and offered them to the mountain gods. After some time, he buried them underground together with his charcoal. This is how the area came to be known as Niwatorizaka. It is written as such in Tōta gyōjō 藤太行状, published in the Jōkyō 貞享 3 (1686). Furthermore, in the Fourth Month of Bunka 文化 15 (1819), a farmer living in the same village went up the mountain to dig for gold and discovered the pair of golden chickens. They weighed approximately one hundred monme 銭目, and engraved on them were the two characters 山神 (mountain god). ${ }^{11}$

This describes how the recent discovery of buried treasures has verified the legends of the golden chickens that have been transmitted in the Tōhoku region since ancient times. After investigating other areas, it became apparent that such golden chicken legends were not only known in Tōhoku, but also in various places throughout Japan. A few such examples are presented below.

About fifty meters from Shōhōji Temple 正法寺 in Aitani, Sakaaibe, in the Uchi District of Nara, there is a place called Hanabatake 花畑. A golden chicken is buried here, which is said to cry out on the morning of New Year's Day. A wealthy man once lived in Uchimura in the same district, in a place called Arazaka. On his estate was a pond with a stone bridge, under which a golden chicken was buried, and when the morning of New Year's Day arrived it was said to cry out. ${ }^{12}$ In Kanage, Oimura in Kyoto Prefecture, there is a mound known as Dairizuka 大理塚. It is told that a noble prince was once buried alive here. His soul trans-

\footnotetext{
${ }^{11}$ Matsura Seizan 松浦静山, Kasshi yawa zokuhen 甲子夜話続篇, vol. 1, eds. Nakamura Yukihiko 中 村幸彦, Nakano Mitsutoshi 中野三敏. Tokyo: Heibonsha, 1979 .

${ }^{12}$ Tamura Yoshinaga 田村吉永, “Chöja to kin no niwatori” 長者と金の鶏, Kyōdo kenkyuu 郷土研究, 2: 3, 1914.
} 
formed into a golden bird which appears and cries out each year on New Year's morning. ${ }^{13}$

Furthermore, the following description is found among the legends of Kiso Valley (Kisodani 木兽谷) in Shinshū Province.

Long ago, there was a wealthy man named Kurashina sama 倉科様 who lived in Matsumotodaira. One year, he went to the capital planning to display his treasures in a competition, and packing up a multitude of them, he set off on Kisokaidō Road 木曽街道. One evening while taking his lodging in Tsumago, three robbers attempted to steal his riches. One of them entered the inn and warmed up the foot of a chicken. This triggered the bird to crow in the middle of the night as if to signal the coming of dawn, thereby tricking the man into setting back onto the road in the darkness. The wealthy man travelled along the Magome Tōge 馬籠峠 mountain pass until he arrived at a place called Aza Otaru 字男垂. The three robbers came up behind the man and stabbed him with a bamboo spear, killing him. They took his treasures and fled. Among their plunder was a golden chicken which fell into the river, disappearing under the waterfall basin at Otaru男垂. Even to this day, it is said that the chicken crows at the break of dawn each New Year's morning. ${ }^{14}$

Among the treasures was a chicken which announced the break of dawn, indicating its presence. The possible meaning behind such a legend, however, is a matter that has yet to be resolved.

Furthermore, from Tokushima prefecture there is the following account.

In Kuwanomura, Naka District, Tokushima, there flows a river that is approximately fifteen ken 間 in width. It is the upper course of Kuwano River 桑野川. Long ago, an itinerant rokubu 六部 monk who was travelling through the village requested to stay the night at the home of a wealthy man, who gladly obliged (I will omit his name). However, he heard that the monk had a golden chicken stored together with a mosquito net in a square box measuring one sun 寸 all around. When the monk departed early the following morning, the wealthy man followed behind and killed him with a blade near a murky pool of water. The golden chicken flapped its wings noisily and flew away, leaving the man with just the mosquito net. Even to this day, the water in the pool is dyed red with the blood of the monk. From this time forward, the people of this house only made rice cakes using pre-ground flour, as those made with steamed rice would always become tainted with his blood. It is said that the family still owns the mosquito net. ${ }^{15}$

This story is called Rokubugoroshi 六部殺 $L,{ }^{16}$ and can be considered a variant tale of Jun'ichi Nomura's 野村純一 Konna ban e no ashidori こんな晚への足取

\footnotetext{
${ }^{13}$ Kakita Ioji 垣田五百次 and Tsuboi Tadahiko 坪井忠彦, Kuchi tamba kōhishū 口丹波口碑集. Tokyo: Kyōdo Kenkyūsha, 1925.

${ }^{14}$ Hayashi Rokurō 林六郎, “Kiso Tsumago yori” 木曾妻籠より, Kyōdo kenkyuu 郷土研究 4: 9, 1916.

${ }^{15}$ Yoshikawa Yasuto 吉川泰人, “Nigori ga fuchi”濁りが淵, Kyödo kenkyū, 1: 2, 1913.

${ }^{16}$ Komatsu Kazuhiko 小松和彦 has written about Rokubugoroshi in his Ijinron: Minzoku shakai no shinsei 異人論一民俗社会の心性一. Tokyo: Seidosha, 1985.
} 
り.$^{17} \mathrm{It}$ is interesting to note that the travelling monk's golden chicken vanished without being stolen. A common feature among such legends is that the golden chicken crows on New Year's morning, and in doing so, the chicken which symbolises wealth asserts its presence by revealing the border between the old year and the new. From the motif of the rice cake, we can conjecture that this final legend from Tokushima was narrated in relation to the new year, or in other words, to the transition point between the years.

Further investigation is required into the relationship that such tales draw between buried gold and the shape of the chicken, and furthermore, what effect this connection has on chicken legends and folklore at large. The fact that the chicken momentarily vanishes from this world and reveals itself at the border of time must somehow be connected to the fact that the gold is transformed into the shape of the chicken. In other words, the gold (or the golden chicken) ought to be buried out of sight, and yet it announces its presence at the start of every new year, which constitutes the most significant barrier of time. This also indicates that the boundary-related nature of the chicken is repeatedly recalled on an annual basis. The relationship between chickens and boundaries in folklore indeed bears multiple layers of meaning.

\section{Afterword}

According to a report by Hayakawa Kōtarō 早川孝太郎 on the Higashi-mikawa district of Aichi prefecture, it was because the chicken was a niwatori 庭鳥, or "garden bird", that it occupied the doma 土間 (dirt floor) area of the home. He writes that the Kamadogami 竈神 (lit. stove god), Dokosshin 土公神 (god of the earth), enjoys watching the chicken at play, and that the chicken's act of waking up early each morning, rustling its wings and crowing serves to clear away the evil spirits of the day. ${ }^{18}$ In times long past, chickens commonly lived alongside humans and it seems that it was because of this that they came to be attributed with boundary-related qualities and meaning. Chickens inhabited the doma, a space imbued with the dual character of both the inside and outside realms, and through the power of its voice the chicken divided night from day.

In general, most chicken folklore is associated with contextually and temporally specific transformation or change. Transmissions of such lore elicit in us recollections of the boundary-related character and symbolism of the chicken which have been largely forgotten in present times. By reviving these narratives however, our past feelings toward the chicken are reawakened and we are able to

\footnotetext{
${ }^{17}$ See, for example, Nihon no sekenbanashi 日本の世間話. Tokyo: Tōkyō Shoseki, 1995.

${ }^{18}$ Dokōshin is the most significant boundary-related divinity in Japanese folk custom. For more on this, see Iijima Yoshiharu 飯島吉晴, Kamadogami to kawayagami: ikai to kono yo no sakai 䥾 神と則神一異界と此の世の境一. Tokyo: Kōdansha Gakujutsu Bunko, 2007 (1 $1^{\text {st }}$ ed. 1986). For more on the chicken's role in ridding the day of evil spirits, see Hayakawa Kōtarō's 早川孝太郎 “Tori no hanashi sono ta” 雞の話其他, Minzoku, 1: 1, 1925.
} 
see in a new light the potential and latent strength lying in the boundaries of space and time. This will also be valuable as the first step toward uncovering the historical relationship between mankind and birds.

\section{References}

Ōtō Tokihiko 大藤時彦, “Kinkei densetsu” 金雞伝説, in Nibon minrokugaku no kenkyȳ 日本民俗学の研究. Tokyo: Gakuseisha, 1979 (1 ${ }^{\text {st }}$ ed. 1972).

Takasaki Masahide 高崎正秀, “Kintarō tanjō tan” 金太郎誕生譚, in Takasaki masabide chosakushū 高崎正秀著作集 7. Tokyo: Ōfūsha, 1971 (1 $\left.{ }^{\text {st }} \mathrm{ed} .1937\right)$.

Takamatsu Keikichi 高松敬吉, “Kainan shisha e no girei” 海難死者への儀礼, in Furoku to takaikan no min rokugakuteki kenkyu 巫俗と他界観の民俗学的研究. Tokyo: Hōsei Daigaku Shuppankyoku, 1993.

Minakata Kumagusu 南方熊楠, “Tori ni kansuru densetsu” 鶏に関する伝説, in Jünishikō 十二支考. Tokyo: Iwanami Shoten, 1994 (1 ${ }^{\text {st }}$ ed. 1951).

Hayakawa Kōtarō 早川孝太郎, “Tori no hanashi sono ta” 雞の話其他, Min₹oku, 1: 11925.

Yanagita Kunio 柳田國男, Zōho santō mintanshū 増補山島民譚集”, eds. Seki Keigo 関敬吾 and Ōtō Tokihiko 大藤時彦, Tokyo: Heibonsha, 1969. 